\title{
Memediasi Pertumbuhan Ekonomi Dengan Kemiskinan: Studi Kasus Provinsi Daerah Istimewa Yogyakarta
}

\author{
Nur Wani ${ }^{1^{*}}$, Suharno ${ }^{2}$, Arintoko ${ }^{3}$ \\ 1,2,3 Fakultas Ekonomi dan Bisnis, Universitas Jenderal Soedirman \\ Jl. Prof. Dr. H.R. Boenyamin No.708, Kabupaten Banyumas, 53122 Indonesia \\ *e-mail : wanisetia46@gmail.com
}

\begin{tabular}{|c|c|}
\hline & ABSTRAK \\
\hline $\begin{array}{c}\text { Artikel Info } \\
\text { Received: } \\
\text { 18 Januari } 2020 \\
\text { Revised: } \\
\text { 09 Juni } 2020 \\
\text { Accepted : } \\
\text { 11 Juni } 2020\end{array}$ & $\begin{array}{l}\text { Hasil-hasil studi empiris terdahulu tentang pengaruh pertumbuhan } \\
\text { ekonomi dengan kemiskinan menunjukkan hasil yang } \\
\text { bertentangan. Oleh karena itu, penelitian ini mencoba } \\
\text { memperkenalkan kesempatan kerja sebagai variabel mediasi } \\
\text { Tujuan penelitian yaitu menguji apakah kesempatan kerja mampu } \\
\text { memediasi antara pertumbuhan ekonomi dengan kemiskinan } \\
\text { Penelitian ini menggunakan data sekunder Provinsi DIY dalam } \\
\text { kurun waktu 2000-2018. Metode dalam penelitian in } \\
\text { menggunakan analisis path. Hasil penelitian menunjukkan bahwa } \\
\text { ketiga hipotesis di atas didukung. Dengan demikian, pertumbuhan } \\
\text { ekonomi akan mampu dalam menurunkan jumlah penduduk miskin } \\
\text { apabila pertumbuhan ekonomi tersebut mampu menumbuhkan } \\
\text { kesempatan kerja. Temuan tersebut mengimplikasikan pentingnya } \\
\text { pertumbuhan inklusif yang memberikan akses kepada penduduk } \\
\text { miskin terhadap pekerjaan dan kesempatan berusaha. } \\
\text { Kata Kunci: Pertumbuhan ekonomi, kesempatan kerja, } \\
\text { kemiskinan, analisis jalur }\end{array}$ \\
\hline Mediating Ecor & $\begin{array}{l}\text { Growth With Poverty : Care Study of The Special } \\
\text { Province of Yogyakarta. }\end{array}$ \\
\hline
\end{tabular}

ABSTRACT

The results of empirical studies on the effect of economic growth with poverty show conflicting results. Therefore, this study tries to introduce employment opportunities as a mediating variable. The research objective is to examine whether employment opportunities are able to mediate between economic growth and poverty. The data used in this study are secondary data of DIY Province in the period 2000-2018. The method used in this research is path analysis. The results showed that the three hypotheses above were supported. Thus, economic growth will be able to reduce the number of poor people if the economic growth is able to grow employment opportunities. The finding implies the importance of inclusive growth that gives poor people access to work and business opportunities.

Keywords : economic growth, employment, poverty, path analysis 


\section{PENDAHULUAN}

Tujuan dari pembangunan yakni ekonomi yang bertumbuh dan jumlah penduduk miskin yang semakin menurun (Kakwani dan Son, 2010). Hal tersebut didasarkan pada teori yang dikemukakan oleh Arthur Lewis (1954) yang selanjutnya dikembangkan oleh Ranis dan Fei (1968), yaitu teori trickle-down effect. Pada dekade 1950-an dan 1960-an, teori trickle-down effect menjadi salah satu topik dalam literatur mengenai pembangunan ekonomi di least developed countries/LDCs (Aghion \& Bolton, 1997). Dalam teori ini menerangkan bahwa kemajuan sekelompok masyarakat otomatis menetes ke kelompok bawah. Dengan demikian diharapkan dapat menciptakan kesempatan kerja yang tinggi dan memperlebar peluang untuk meningkatkan perekonomian sehingga dapat manfaat pertumbuhan ekonomi dapat dirasakan oleh masyarakat secara merata (Todaro dan Smith, 2011).

Menurut Todaro dan Smith (2011), beberapa faktor yang mempengaruhi variasi penduduk miskin di negara berkembang, antara lain, yaitu: (1) kualitas sumber daya manusia dan sumber daya alam yang berbeda, (2) struktur industri yang berbeda, (3) kondisi geografis, demografi dan pendapatan yang berbeda (4) pembagian peran sektor negara dan swasta, (5), perbedaan histori negara, dikarenakan perbedaan negara penjajah (6) ketergantungan akan kekuatan ekonomi serta politik di negara lain dan (7) pembagian kekuasaan, politik dan kelembagaan.

Pertumbuhan ekonomi memiliki korelasi terhadap jumlah penduduk miskin, dimana pertumbuhan ekonomi yang tinggi akan berdampak pada penurunan jumlah penduduk miskin, dengan asumsi bahwa pertumbuhan ekonomi berpihak pada penduduk miskin (Kakwani et al. 2010). Siregar \& Wahyuni (2007) menjelaskanpengurangan jumlah penduduk miskin menjadi syarat dalam pertumbuhan ekonomi. Dalam hal ini, semua penduduk dengan berbagai golongan pendapatan, tak terkecuali penduduk yang termasuk dalam golongan kelompok miskin harus mampu dirangkul oleh pertumbuhan ekonomj (growth with equity). Oleh karenanya hal ini perlu menjadi perhatian khusus sektor yang dimana penduduk miskin bekerja apakah pertanian atau sektor yang padat karya. Selain itu, pemerintah perlu berperan secara intensif dalam upaya menyebarkan dampak dari adanya pertumbuhan ekonomi yang bisa berasal dari sektor modern seperti manufaktur dan jasa yang padat modal.

Namun demikian, hasil-hasil penelitian terdahulu menunjukkan hasil-hasil yang bertentangan. Beberapa peneliti seperti Suliswanto (2010), Miranti (2010), Guiga (2012), Paramita \& Purbadharmaja (2015), Datt et al. (2016), dan Moore \& Donaldson (2016) menemukan bahwa pertumbuhan ekonomi berpengaruh linier dan negatif terhadap angka kemiskinan. Artinya kenaikan pertumbuhan ekonomi diikuti dengan penurunan angka kemiskinan. Namun demikian, para peneliti lain seperti Jha et al.(2000), Soleh (2011), Afzal et al. (2012), Iswara (2014), dan Berardi \& Marzo (2017) menjelaskan dalam temuannya yang menyebutkan jumlah penduduk miskin yang menurun tidak serta merta dipengaruhi secara langsung oleh pertumbuhan ekonomi.

Penelitian ini mencoba menjelaskan perbedaan temuan penelitian tersebut dengan memperkenalkan variabel mediasi yaitu kesempatan kerja. Hal ini didasarkan pada argumentasi Jonaidi (2012) yang menyatakan bahwa pertumbuhan ekonomi yang tinggi mampu membuka lapangan kerja yang banyak. Yarlina (2012) dan Danawati, Bendesa, \& Suyana Utama (2016) menjelaskan bahwa kesempatan kerja berperan dalam menentukan pengaruh antara pertumbuhan ekonomi dan penurunan jumlah penduduk miskin. Selain itu, Awandari \& Indrajaya (2016) dalam temuannya menjelaskan bahwa kesempatan kerja dan angka kemiskinan memiliki hubungan yang sangat erat. 


\section{EKONOMIKAWAN : Jurnal Ilmu Ekonomi dan Studi Pembangunan}

I55N : $1693-7600$ (Print), 155N : 2598-0157 (Online), hutp:/fumal.umstiac.id//ndex,php/ekawan

Penelitian ini secara purposive mengambil sampel Provinsi Daerah Istimewa Yogyakarta (DIY) karena fenomena yang menarik. Provinsi DIY menunjukkan kinerja perekonomian pesat sebagaimana terlihat pada pertumbuhan ekonominya selama 20132017 yang selalu lebih tinggi dari angka nasional. Namun demikian, angka kemiskinannya selama periode tersebut masih tinggi dibandingkan angka kemiskinan nasional. Dengan demikian, kemiskinan di provinsi Daerah Istimewa Yogakarta perlu untuk mendapatkan perhatian khusus dari pemerintah daerah maupun pusat. Berikut adalah tabel 1 yang menunjukkan angka kemiskinan dan pertumbuhan ekonomi di Provinsi Daerah Istimewa Yogyakarta.

Tabel 1. Pertumbuhan Ekonomi dan Angka Kemiskinan Indonesia dan DIY 2013-2018 (Persen)

\begin{tabular}{ccccc}
\hline \multirow{2}{*}{ Tahun } & \multicolumn{2}{c}{ Pertumbuhan Ekonomi } & \multicolumn{2}{c}{ Angka Kemiskinan } \\
\cline { 2 - 5 } & Indonesia & DIY & Indonesia & DIY \\
\hline 2013 & 5,56 & 5,57 & 11,42 & 15,23 \\
2014 & 5,02 & 5,17 & 11,11 & 14,77 \\
2015 & 4,79 & 4,95 & 11,76 & 14,03 \\
2016 & 5,02 & 5,03 & 10,78 & 13,25 \\
2017 & 5,07 & 5,26 & 10,12 & 12,69 \\
2018 & 5,17 & 6,20 & 9,82 & 11,81 \\
\hline
\end{tabular}

Sumber : Badan Pusat Statistik DIY (BPS), 2018.

Berdasarkan uraian di atas hal yang melatarbelakangi penelitian ini yaitu perbedaan hasil-hasil penelitian tentang pengaruh pertumbuhan ekonomi terhadap kemiskinan dengan memilih sampel DIY yang memiliki karakteristik unik yaitu menunjukkan pertumbuhan ekonomi yang tinggi (melebihi angka pertumbuhan nasional) namun angka kemiskinannya juga lebih tinggi daripada angka nasional. Dengan demikian dapat dirumuskan tujuan penelitian ini adalah menguji apakah kesempatan kerja mampu memediasi anatra pertumbuhan ekonomi terhadap kemiskinan.

\section{KAJIAN TEORI}

\section{Pertumbuhan Ekonomi}

Pembangunan ekonomi di suatu wilayah dapat dianalisis dengan menggunakan suatu indikator yaitu pertumbuhan ekonomi. Aktifitas perekonomian di suatu wilayah menunjukan upaya meningkatkan kesejahteraan masyarakat dalam suatu periode tertentu dapat ditunjukkan melalui pertumbuhan ekonomi (Ginting dan Rasbin, 2010). Produksi tahun tertentu yang menunjukkan hasil yang didapatkan lebih besar dari tahun sebelumnya, menandakan bahwa perekonomian mengalami pertumbuhan. Dengan kata lain, perekonomian yang mengalami pertumbuhan terjadi apabila pendapatan riil tahun sebelumnya lebih kecil dari pendapatan riil tahun ini atau pendapatan riil mengalami peningkatan. Pertumbuhan Produk Domestik Bruto menjadi indikatar dalam pengukuran pertumbuhan ekonomi (Todaro dan Smith, 2011).

Perubahan dalam faktor produksi fisik (tabungan dan investasi) dan tenaga kerja akan mempengaruhi pertumbuhan ekonomi, sementara tingkat efisien yang digambarkan oleh teknologi dianggap sebagai variabel eksogen dan residual merupakan asumsi yang ada dalam model solow. Persamaan pertumbuhan ekonomi dalam model pertumbuhan HarrodDomar dikembangkan dengan menambahkan faktor teknologi dan tenaga kerja menjadi sebual model baru yang dikenal sebagai model Solow. Diminishing return terjadi apabila 
modal dan tenaga kerja dianalisis secara terpisah, sedangkan constant return to scale terjadi jika penganalisisan modal dan tenaga kerja dilakukan secara bersama-sama (Tadaro dan Smith, 2011). Model pertumbuhan neoklasik Sollow memakai fungsi produksi agregat standar yaitu:

$$
\mathrm{Y}=\mathrm{K}^{\alpha}(\mathrm{AL})^{1-\alpha}
$$

Dimana $\mathrm{Y}$ ialah GDP atau pertumbuhan ekonomi, $\mathrm{K}$ adalah modal, $\mathrm{L}$ ialah labour sedangkan A ialah produktivitas tenaga kerja yang pertumbuhannya ditentukan secara eksogen. Simbol $\alpha$ menunjukkan elastisitas output terhadap modal.

Sumber pertumbuhan output dalam teori pertumbuhan neoklasik terdiri dari satu atau lebih dari tiga faktor, yaitu peningkatan kualitas dan kuantitas tenaga kerja (melalui pendidikan yang diperbaiki dan pertumbuhan ekonomi), modal yang bertambah (melalui tabungan dan investasi dan teknologi yang disempurnakan.

Kuznet dalam (Jhingan, 2000) mengemukakan bahwa berdasarkan produk nasional dan komponennya terdapat 6 ciri pertumbuhan ekonomi, diantaranya:

1. Pendapatan per kapita dan pertumbuhan penduduk;

2. Produktivitas yang meningkat;

3. Peralihan struktural yang tinggi;

4. Perpindahan penduduk;

5. Negara maju yang berkembang pesat; dan

6. Modal dan arus barang antar negara.

Ada kaitan satu sama lain yang terdapat pada ciri pertumbuhan ekonomi tersebut. Adam Smith, David Ricardo, Thomas Robert Malthus, dan Jhon Stuart Mill yang merupakan ekonom klasik menjelaskan bahwa pertunbuhan ekonomi dipengaruhi oleh empat faktor, yaitu sebagai berikut:

1. Pertumbuhan penduduk;

2. Stok barang modal;

3. Kekayaan alam; serta

4. Kualitas teknologi yang dipakai.

Menurut Todaro dan Smith (2011) ada tiga faktor utama dalam pertumbuhan ekonomi, yaitu :

1. Akumulasi modal

Tanah (lahan), SDM (human resources), peralatan fisik (mesin) menjadi salah satu bentuk investasi baru yang dinamakan sebagai akumulasi modal. Terjadinya akumulasi modal jika menginvestasikan sebagian tabungan yang didapatkan dari pendapatan sekarang guna meningkatkan jumlah output dimasa yang akan datang. Perbaikan infrastruktur seperti jalan, air, listrik, komunikasi, sanitasi harus disertakan dalam investasi guna menunjang produktifnya aktivitas ekonomi. Pembinaan sumber daya manusia merupakan investasi yang didasarkan pada kualitas modal manusia yang meningkat dan akhirnya angka produksi akan berdampak positif.

2. Pertumbuhan Penduduk dan Angkatan Kerja

Jumlah angkatan kerja (labor force) secara tradisional yang mengalami peningkatan dan berhubungan dengan pertumbuhan penduduk dapat dikatakan sebagai faktor yang positif dalam pertumbuhan ekonomi. Artinya, semakin produktif tenaga kerja disebabkan banyaknya angkatan kerja yang meningkat, sedangkan peningkatan potensi pasar akan terjadi bila semakin banyak penduduk. 
I55N : $1693-7600$ (Print), 155N : 2598-0157 (Online), hutp://fumal_umstiac.id//index.php/ekawan

3. Kemajuan Teknologi

Perbaikan dari teknologi dengan cara baru dan cara lama yang dilakukan dengan pekerjaan tradisional mengakibatkan adanya kemajuan teknologi. Tiga klasifikasinya :

a. Perkembangan teknologi yang bersifat netral, artinya pada kuantitas dan kombinasi input yang sama akan menyebabkan peningkatan tingkat output yang dicapai.

b. Perkembangan teknologi yang bersifat hemat tenaga kerja atau hemat modal, artinya jumlah tenaga kerja atau input modal yang tetap akan menyebabkan tingginya tingkat output yang dicapai.

c. Perkembangan teknologi yang meningkatkan modal, terjadi jika ada kemungkinan untuk memanfaatkan barang modal yang ada secara lebih produktif dalam menggunakan teknologi.

\section{Kemiskinan}

Keadaan dimana pemenuhan kebutuhan dasar tidak dapat tercukupi dengan pendapatan masyarakat yang didapat dinamakan sebagai kemiskinan ((Kuncoro, 2006). Indikator pengukuran kemiskinan dari Badan Pusat Statistik (BPS) adalah dengan menggunakan konsep kemampuan pemenuhan kebutuhan dasar (basic needs approach). Dengan demikian, yang diartikan sebagai kemiskinan adalah sebuah keadaan dimana masyarakat kurang mampu dalam pemenuhan kebutuhan dasarnya baik makanan maupun non makanan yang dilihat dari sisi pengeluaran. Sementara itu, penduduk yang rata-rata pengeluaran perkapitanya berada dibawah garis kemiskinan dinamakan sebagai penduduk miskin. Selain itu, World Bank (2011) membuat ketentuan dalam mengukur jumlah penduduk miskin. Ukuran tersebut menggunakan pendekatan kemampuan daya beli atau Purchasing Power Parity (PPP) apabila konsumsi per kapita kurang dari USD2 per hari maka dapat dikategorikan penduduk miskin. Ukuran kemiskinan tersebut, berbeda dengan pemerintah Indonesia, kemiskinan diukur dengan menghitung kebutuhan pangan seorang dalam sehari, diukur dengan satuan kalori, kemudian dikalikan dengan harga.

Menurut undang-undang Nomor 13 Tahun 2011 mendefinisikan kemiskinan sebagai kondisi dimana tidak terjadinya pemenuhan hak-hak dasarnya seseorang atau sekelompok orang dalam mempertahankan dan melanjutkan kehidupannya. Hak-hak dasar tersebut yang harus dipenuhi diantaranya kebutuhan pangan, kesehatan, rasa aman, lingkungan hidup, partisipasi dalam penyelenggaraan sosial dan politik, serta pertahanan sumber daya alam.

Ragnar Nurkse dalam (Kuncoro, 2006) mengemukakan teori lingkaran setan kemiskinan Teori lingkaran setan kemiskinan (vicious circle of poverty), yaitu " $a$ poor country is poor because it is poor", yang artinya masyarakat miskin yang menyebabkan negara miskin. Produktivitas rendah disebabkan oleh adanya keterbelakangan, keterbatasan modal yang diikuti ketidak sempurnaan pasar. Upah yang diterima rendah disebabkan karena produktivitas yang rendah. Upah atau pendapatan rendah ini akan berdampak langsung pada tingkat tabungan dan investasi yang rendah. Pada akhirnya rendahnya investasi ini akan menyebabkan kondisi menjadi keadaan awal dan seterusnya yang membentuk sebuah gambar lingkaran seperti dibawah ini. 


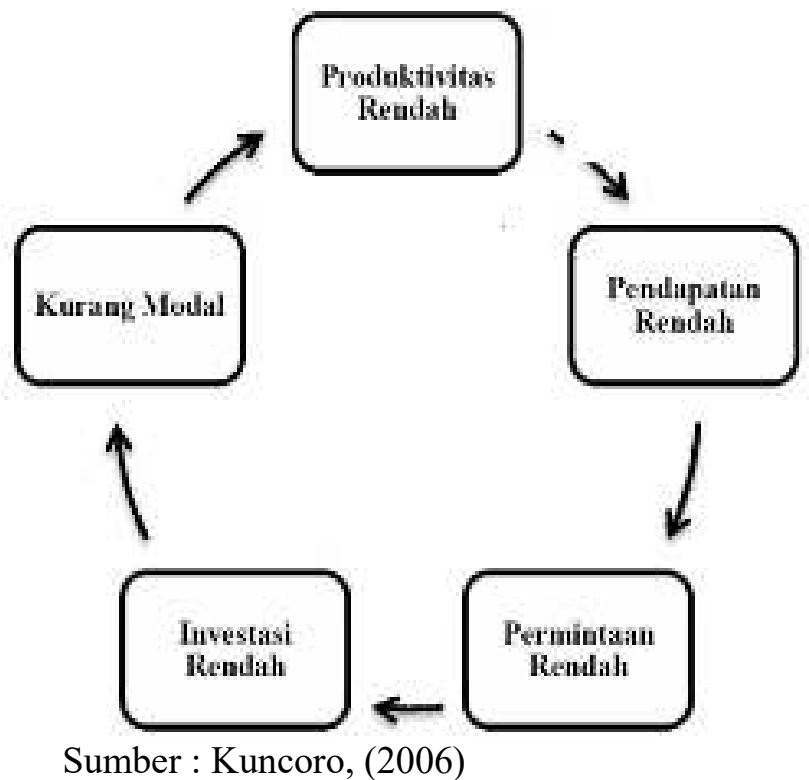

Gambar 1. Lingkaran Setan Kemiskinan ( The Vicious Circle of Proverty)

Kemiskinan bersifat multi dimensional artinya kemiskinan dapat dilihat dari berbagai sisi seperti budaya, sosial, dan politik. Selain itu, definisi kemiskinan diperluas lagi pada awal 1990-an dimana tidak hanya didasarkan pada tingkat pendapatan melainkan juga dengan tingkat ketidakmampuan dalam pemenuhan kebutuhan hidup seseorang atau sekelompok orang baik dalam bidang pendidikan, kesehatan, ataupun perumahan (papilaya, 2006).

Lembaga penelitian SMERU mengemukakan bahwa definisi kemiskinan yang baik meliputi dari berbagai dimensi, diantaranya:

1. Akses kebutuhan dasar hidup lainnya (kesehatan, air bersih, pendidikan, sanitasi, dan transportasi) tidak mampu dicapai.

2. Tidak adanya jaminan untuk kehidupan di masa mendatang (investasi dalam pendidikan dan kesehatan tidak tersedia).

3. Rentan terhadap perubahan yang bersifat individual atau kelompok.

4. Sumber daya alam dan sumber daya manusia yang terbatas.

5. Partisipasi dalam kegiatan sosial dan politik kurang diberikan.

6. Akses lapangan kerja yang tidak tersedia.

7. Adanya cacat fisik maupun mental sehingga tidak mampu untuk berusaha.

8. Kurang beruntung dalam bidang sosial (wanita korban tindak kekerasan, anak telantar, kelompok marginal, dan terpencil).

Krisnamurthi (2006) mengemukakan pengklasifikasian kemiskinan dalam beberapa kelompok sesuai dengan kondisi yang dihadapi, diantaranya:

1. Kemiskinan absolut, terjadi karena tingkat pendapatan atau pengeluaran yang berada di bawah garis kemiskinan dalam pemenuhan kebutuhan hidup layak.

2. Kemiskinan relatif, terjadi apabila tingkat pendapatan dan pengeluarannya relatif lebih rendah dibandingkan dengan pendapatan masyarakat lain.

3. Kemiskinan kronis (chronic) atau struktural, terjadi secara jangka panjang dan kondisi miskin yang terus menerus. 
4. Kemiskinan sementara (transitory) atau accidental, terjadi karena adanya perubahan yang menyebabkan shock dan mengubah masyarakat yang tadinya tidak miskin menjadi miskin.

5. Kemiskinan massal, terjadi karena sebagian masyarakat mengalami kemiskinan.

6. Kemiskinan individual, terjadi di sebagian kecil masyarakat atau beberapa orang yang mengalami kemiskinan.

\section{Kesempatan Kerja}

Menurut Danawati et al., (2016) kesempatan kerja adalah sebuah peluang usaha atau lapangan usaha yang tersedia bagi masyarakat dimana kesempatan kerja juga mencakup lapangan kerja yang sudah terisi sehingga memberikan peranan penting dalam pembangunan. Sukirno (2010) mengatakan bahwa kesempatan kerja merupakan sebuah kondisi ketika seluruh pekerja yang memiliki keinginan untuk bekerja dengan tingkat upah tertentu dapat dengan mudah mendapatkan pekerjaan.

Kesempatan kerja menunjukan permintaan terhadap tenaga kerja karena permintaan tenaga kerja di pasar kerja menciptakan adanya kesempatan kerja.Lapangan pekerjaan yang sudah ditempati menjadi salah satu kesempatan kerja (Tambunan, 2002). Prospek utama atau pertumbuhan dari perusahaan tersebut, harga faktor produksi lain yang dapat menggantikan fungsi tenaga kerja, dan gaji yang harus dibayarkan atau ongkir tenaga kerja merupakan faktor yang paling utama dalam kebutuhan tenaga kerja yang dibutuhkan perusahaan atau lapangan pekerjaan yang masih kosong. Perluasan kesempatan kerja produktif merupakan kondisi dimana produktivitas kerja meningkat dan disertai dengan pemberian gaji yang sesuai dengan yang telah dikerjakan oleh setiap pekerja.

\section{Hubungan Pertumbuhan Ekonomi dengan Kemiskinan Melalui Variabel Mediasi Kesempatan Kerja}

Menurut Todaro dan Smith (2011) pertumbuhan ekonomi adalah suatu proses ataau kegiatan yang mampu meningkatkan kapasitas produksi secara nasional dalam kurun tertentu. Pertumbuhan ekonomi yang inklusif yaitu pertumbuhan ekonomi yang merata diman dampak dari pertumbuhannya dapat dinikmati oleh semua kalangan masyaraka (Hasan \& Quibria, 2002). Pertumbuhan ekonomi hakikatnya akan dapat meningkatkan kesempatan kerja yang lebih tinggi. Hal ini dikarenakan apabila terjadi peningkatan kapasitas produksi nasional tentunya diiringi dengan terciptanya lapangan pekerjaan (Jonaidi, 2012). Dengan demikian pertumbuhan ekonomi mampu menurunkan angka kemiskinan dengan terjadi peningkatan lapangan kerja yang tinggi, sehingga kesempatan kerja merupakan variabel mediasi yang menghubungkan antara pertumbuhan ekonomi dengan kemiskinan. Yarlina (2012) dan Danawati, Bendesa, \& Suyana Utama (2016)Awandari \& Indrajaya (2016) menjelaskan bahwa kesempatan kerja berperan penting dalam menentukan proses pengaruh antara tingkat kemiskinan yang menurun dan pertumbuhan ekonomi. Dengan demikian dapat dirumuskan hipotesis bahwa hubungan antara pertumbuhan ekonomi dengan kemiskinan dapat melalui kesempatan kerja sebagai mediasi.

\section{METODE}

Dalam penelitian ini, pendekatan kuantitatif digunakan sebagai metode penelitian. Sampel dalam penelitian ini adalah di Provinsi DIY yang menggunakan data sekunder rutun waktu atau times series. Objek dalam penelitian ini adalah pertumbuhan ekonomi terhadap angka kemiskinan dengan kesempatan kerja sebagai variabel intervening pada di 
DIY tahun 2010 - 2017. Kemiskinan dan pertumbuhan ekonomi diukur dengan satuan persentase. Variabel dependen dalam penelitian ini adalah kemiskinan, sedangkan variabel independennya adalah angka kemiskinan dengan variabel intervening kesempatan kerja. Penelitian ini menggunakan teknik analisis jalur (Path Analysis) dalam menjawab pertanyaan penelitian. Dengan alat analisis ini dapat diketahui apakah variabel independen berhubungan langsung terhadap variabel dependen atau berhubungan tidak langsung dengan melalui variabel intervening (Sudaryono, 2011)

Alur pengaruh langsung antara pertumbuhan ekonomi dan kemiskinan tanpa menggunakan variabel mediasi pada dilihat pada Gambar 2.

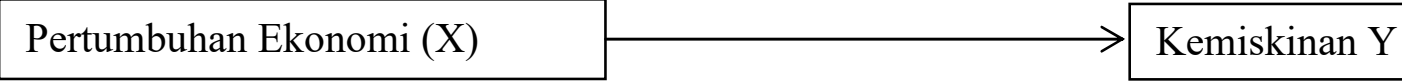

Gambar 2. Model regresi langsung tanpa varaibel intervening

Alur pengaruh antara pertumbuhan ekonomi dengan kemiskinan dengan dimasukan variabel mediasi kesempatan kerja dapat dilihat pada gambar 3.

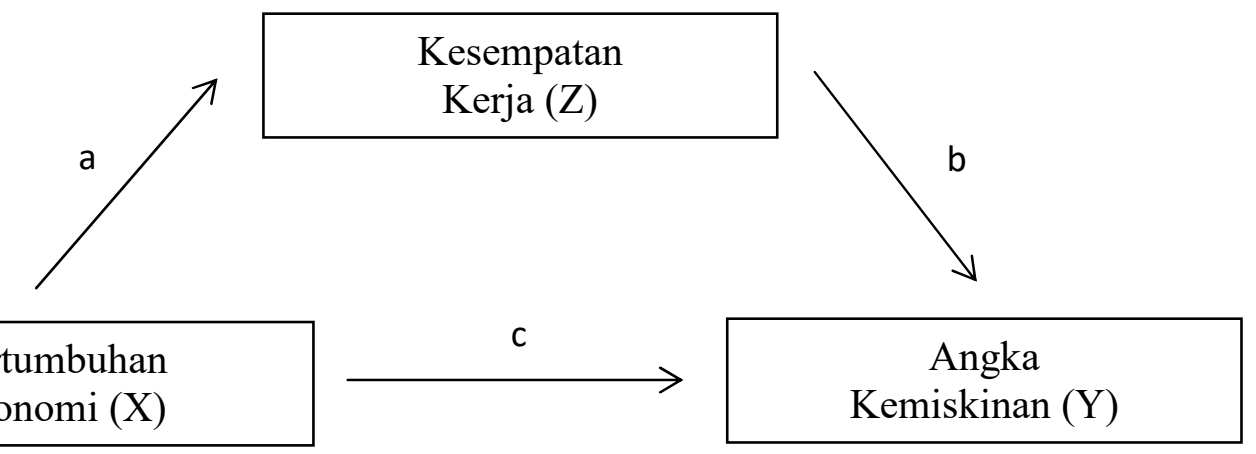

Gambar 3. Model regresi melalui variabel mediasi.

Variabel mediasi dianalisis dengan menggunakan metode kausal step yang dikembangkan oleh (Baron \& Kenny, 1986). Berikut ini tahapan-tahapan dalam menerapkan metode kausal step :

1. Tahap pertama menyusun persamaan regresi variabel independen $(\mathrm{X})$ dengan variabel dependen (Y)

2. Tahap kedua menyusun persamaan regresi variabel independen $(\mathrm{X})$ dengan variabel mediasi (Z)

3. Tahap ketiga menyusun persamaan regresi variabel independen $(\mathrm{X})$ dengan variabel dependen (Y) dan menambahkan variabel mediasi (Z)

4. Tahap terakhir yaitu menyimpulkan apakah variabel mediasi tersebut mampu memediasi secara penuh atau memediasi secara persial.

Tahapan di atas dapat dirumuskan dalam persamaan regresi diawah ini.

Persamaan I

$: Y=\beta_{0}+\beta_{1} X_{1}+e$

dimana:

Y : Pertumbuhan ekonomi

$\beta_{0} \quad$ : Koefisien regresi (Konstanta)

$\beta_{1} \quad$ : Koefisien Regresi (Variabel Kemiskinan)

$\mathrm{X}_{1} \quad$ : Kemiskinan 
I55N : 1693 -7600 (print), $155 N$ : 2598 - 0157 (Online), http://fumalumstiac.id/index.php/ekawan

Persamaan II

e : Error

Persamaan III

$$
: Z=\beta_{0}+\beta_{1} X_{1}+e
$$

dimana:

$$
\begin{array}{ll}
\mathrm{Z} & : \text { Kesempatan kerja } \\
\beta_{0} & : \text { Koefisien regresi (Konstanta) } \\
\beta_{1} & : \text { Koefisien Regresi (Variabel Kemiskinan) } \\
\mathrm{X}_{1} & : \text { Kemiskinan } \\
e & : \text { Error }
\end{array}
$$

$$
\begin{aligned}
& : Y=\beta_{0}+\beta_{1} X_{1}+\beta_{2} Z_{2}+e \\
& \text { dimana: }
\end{aligned}
$$$$
\text { Y : Pertumbuhan ekonomi }
$$$$
\beta_{0} \quad \text { : Koefisien regresi }
$$$$
\beta_{1} \quad \text { : Koefisien Regresi (Variabel Kemiskinan) }
$$$$
\beta_{2} \quad \text { : Koefisien Regresi (Variabel Kesempatan Kerja) }
$$$$
\mathrm{X}_{1} \quad \text { : Kemiskinan }
$$$$
\mathrm{Z}_{2} \quad \text { : Kesempatan kerja }
$$

e : Error

Variabel $\mathrm{Z}$ dapat dikatakan sebagai variabel mediasi apabila memenuhi syarat sebagai berikut.

1. Apabila di persamaan $\mathrm{I}$, variabel independen $(\mathrm{X})$ berpengaruh terhadap variabel dependen (Y)

2. Apabila di persamaan II, variabel independen (X) berpengaruh terhadap variabel variabel mediasi $(Z)$.

3. Apabila di persamaan III, variabel mediasi $(Z)$ berpengaruh terhadap variabel dependen (Y).

Berikut kriteria hasil pengujian atas variabel mediasi menurut Suliyanto (2011):

1. Variabel $\mathrm{Z}$ dapat dikatakan mampu mediasi secara sempurna (perfect mediation) apabila dalam model persamaan regresi dimasukan variabel $\mathrm{Z}$ yang kemudian mengubah pengaruh variabel $\mathrm{X}$ terhadap $\mathrm{Y}$ menjadi tidak signifikan yang sebelumnya berpengaruh signifikan.

2. Variabel $\mathrm{Z}$ dapat dikatakan mampu mediasi secara parsial (partial mediation) apabila tidak berubahnya pengaruh variabel $X$ terhadap $Y$ dimana sebelum dimasukan variabel $\mathrm{Z}$ kedalam persamaan memiliki signifikan dan setelah dimasukan variabel $\mathrm{Z}$ juga tetap signifikan.

\section{HASIL DAN PEMBAHASAN \\ Koefisien model jalur Model I}

Output regresi pada Model I yang menunjukkan hubungan pertumbuhan (X) ekonomi terhadap kemiskinan (Y), dapat dilihat pada Tabel 2.

Tabel 2. Ouput Regresi pengaruh Pertumbuhan Ekonomi (X) dengan Kemiskinan (Y)

\begin{tabular}{lcc}
\hline \multicolumn{1}{c}{ Parameter } & Koefisien Regresi & Probabilitas \\
\hline Konstanta & 6,097389 & 0,0000 \\
$\mathrm{X}$ & $-0,072225$ & 0,0016 \\
\hline$R$-Squared & & 0,4740 \\
\hline
\end{tabular}

Sumber: Data sekunder diolah, 2019. 


\section{EKONOMIKAWAN : Jurnal Ilmu Ekonomi dan Studi Pembangunan}

I55N : $1693-7600$ (Print), 155N : 2598-0157 (Online), hutp:/fumal.umstiac.id//ndex,php/ekawan

Dari Tabel 2 maka dapat dirumuskan persamaan penelitian Model I sebagai berikut ini.

$$
\mathrm{Y}=6,097389-0,072225 \mathrm{X}
$$

a) Berdasarkan output regresi pada Model I dapat diketahui bahwa nilai signifikansi dari variabel pertumbuhan ekonomi (X) sebesar 0,0016 lebih kecil dari tingkat kesalahan sebesar 0,05. Hasil ini menunjukkan kesimpulan bahwa regresi Model I yaitu variabel pertumbuhan ekonomi (X) berpengaruh signifikan terhadap kemiskinan $(\mathrm{Z})$.

b) Pada output regresi Model I menghasilkan besaran nilai $\mathrm{R}$ square adalah sebesar 0,4740. Hal ini mengidentifikasilan bahwa kemiskinan (Z) dipengaruhi oleh pertumbuhan ekonomi (X) dengan besaran varians sebesar 47,40 persen, sedangkan 52,60 persen merupakan variabel lain yang tidak ada dalam model penelitian yang memiliki kontribusi. Dengan demikian, diagram jalur model I yang terbentuk adalah sebagai berikut:

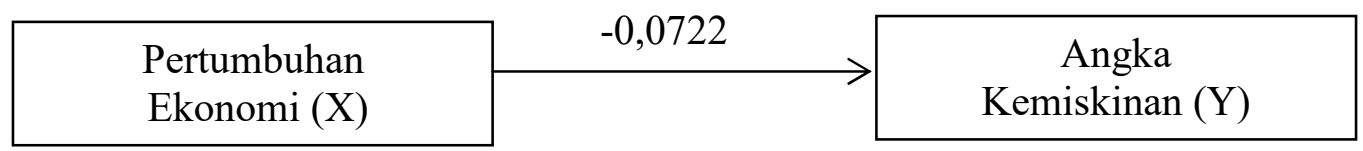

Sumber : Data sekunder diolah, 2019.

Gambar 4. Diagram Jalur Model I

\section{Koefisien model jalur Model II}

Ouput regresi pada Model II menunjukkan bahwa hubungan pertumbuhan (X) ekonomi terhadap kesempatan kerja (Z) terhadap kemiskian (Y), dapat dilihat pada Tabel 3.

Tabel 3. Ouput Regresi Pertumbuhan Ekonomi (X), dan Kesempatan Kerja (Z) terhadap Kemiskinan (Y)

\begin{tabular}{lcc}
\hline \multicolumn{1}{c}{ Parameter } & Koefisien Regresi & Probabilitas \\
\hline Konstanta & 15,6169 & 0,0000 \\
$\mathrm{X}$ & $-3,7920$ & 0,0369 \\
$\mathrm{Z}$ & $-8,2102$ & 0,0073 \\
\hline$R$-Squared & & 0,4740 \\
\hline
\end{tabular}

Sumber: Data diolah, 2019. ini.

Dari Tabel 3 maka dapat dirumuskan persamaan penelitian Model II sebagai berikut

$$
Y=6,097389-3,7920 X-8,2102 Z
$$

a) Berdasarkan output regresi Model II dapat diketahui bahwa nilai signifikansi dari variabel pertumbuhan ekonomi (X) sebesar 0,0369 dan kesempatan kerja (Z) sebesar 0,0073 lebih kecil dari tingkat kesalahan sebesar 0,05. Hal ini menunjukkan bahwa pada regresi Model II variabel pertumbuhan ekonomi $\left(\mathrm{X}_{1}\right)$ dan kesempatan kerja $\left(\mathrm{Z}_{1}\right)$ berpengaruh signifikan terhadap angka kemiskinan $(\mathrm{Y})$

b) Nilai $R$ square pada output regresi Model II adalah sebesar 0,6578. Hal ini menunjukkan bahwa varians pertumbuhan ekonomi $\left(\mathrm{X}_{1}\right)$ terhadap kesempatan kerja $\left(Z_{1}\right)$ sebesar 65,78 persen, sementara sisanya 34,22 persen merupakan kontribusi dari variabel lain yang tidak dimasukan dalam model penelitian 

berikut.

Dari output regresi di atas maka dapat dirumuskan diagram jalur model II sebagai

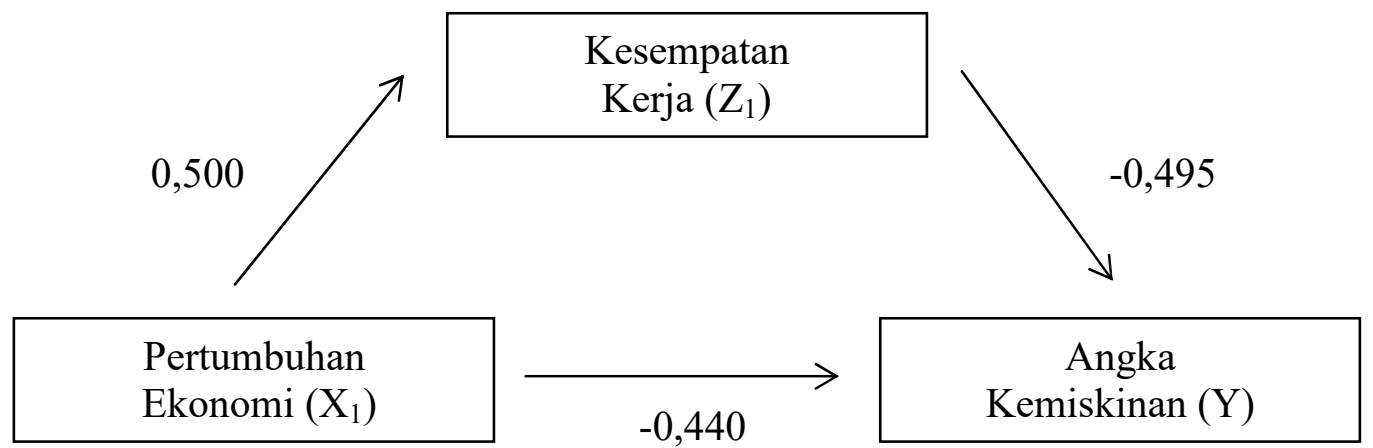

Sumber : Data sekunder diolah, 2019.

Gambar 5. Diagram Jalur Model II

Berdasarkan kriteria pengujian yang menyatakan bahwa variabel mediasi parsial dapat dikatakan sebagai variabel $\mathrm{Z}$ jika pengaruh variabel $\mathrm{X}$ tidak berubah (sebelumnya signifikan dan setelahnya tetap menjadi signifikan) terhadap variabel $\mathrm{Y}$ setelah dimasukkan kedalan persamaan regresi. Dengan demikian, dapat disimpulkan bahwa kesempatan kerja mampu memediasi secara parsial antara pertumbuhan ekonomi dengan kemiskinan di Provinsi DIY.

Penemuan ini sejalan dengan Yarlina (2012), Jonaidi (2012), Hassan, Zaman, \& Gul (2015), dan Danawati, Bendesa, \& Suyana Utama (2016) menjelaskan bahwa kesempatan kerja berperan cukup penting dalam kaitannya antara pertumbuhan ekonomi dan pennurunan jumlah kemiskinan. Selain itu, Awandari \& Indrajaya (2016) dalam temuannya menjelaskan bahwa kesempatan kerja dan angka kemiskinan memiliki hubungan yang sangat erat. Menurut (Aghion \& Bolton, 1997) pertumbuhan ekonomi harus diimbangi dengan bertambahanya jumlah kesempatan kerja. Pengaruh pertumbuhan ekonomi terhadap kemsikinan menghasilkan suatu dasar kerangka pemikira yaitu trickledown effect yang dicetuskan pertama kali oleh Arthur Lewis (1954) dan dikembangkan oleh Ranis dan Fei (1968) dari pertumbuhan ekonomi dalam bentuk peningkatan kesemapatan kerja akan berimbas pada penurunan jumlah pengangguran dan mampu meningkatkan upah. Dengan anggapan bahwa ada mekanisme yang dapat memfasilitasi trickle-down dari pertumbuhan ekonomi kepada penduduk miskin. Dengan demikian dapat disimpulkan bahwa pertumbuhan ekonomi dapat dikatakan alat yang efektif bagi pengurangan jumlah penduduk miskin.

Menurut Dollar dan kraay (2012) pertumbuhan ekonomi akan memberikan kontribusi yang nyata kepada penduduk miskin, apabila pertumbuhan ekonomi disertai dengan instrumen kebijakan yang tepat dari pemerintah dan stakeholder terkait, seperti penegakan hukum yang pasti, disiplin fiskal, dan mekanisme atau upaya mengurangi jumlah penduduk miskin. Selain itu, Bank Dunia memberikan saran untuk menentukan kebijakan, diantaranya adalah mendorong pertumbuhan ekonomi yang mampu menciptakan lapangan kerja untuk meningkatkan pendapatan dan mengurangi jumlah penduduk miskin.

Mengacu pada teori pertumbuhan baru dimana memfokuskan pada kontribusi pemerintah dalam meningkatkan kualitas sumberdaya manusia yang ditunjukkan pada ketrampilan dan ilmu pengetahuan. Dengan bertambahnya ilmu pengertahuan, keahlian dan ketrampilan dapat memacu tingkat produktivitas kerja, yang mengarah untuk 
membantu mengurangi tingkat kemiskinan (Suliswanto (2010). Oleh karena itu, pertumbuhan ekonomi yang mampu mengurangi jumlah penduduk miskin adalah yang bersifat inklusif. Artinya kue dari pertumbuhan ekonomi dapat dirasakan oleh semua elemen masyarakat, baik yang berpenghasilan tinggi maupun yang berpenghasilan rendah. Selain itu, investor yang merupakan pemilik modal yang menyokong pertumbuhan ekonomi harus meningkatkan investasinya. Hal ini dikarenakan investasi akan mempercepat akumulasi modal dalam kegiatan perekonomian nasional dan akumulasi modal manusia dengan melewati pendidikan dan pelatihan, serta pengembangan dan peningkatan infrastruktur pedesaan. Membutuhkan intervensi pemerintah dan partisipasi swasta yang signifikan (Siregar, 2006).

Kombinasi belanja pendidikan dan kesehatan yang disertai dengan peningkatan belanja modal pemerintah memiliki dampak terbesar dalam mengurangi kemiskinan di Indonesia (Mustaqimah et al. 2017). Strategi pembangunan yang tidak hanya memprioritaskan pembangunan fisik, tetapi juga memprioritaskan peningkatan kualitas sumber daya manusia harus digunakan sebagai salah satu langkah strategis dalam pembangunan daerah di Indonesia, karena dampaknya bisa lebih besar dalam mengurangi kemiskinan. Atas perannya yang mendasar bagi kualitas sumber daya manusia, pemerintah harus memperbaiki sistem pendidikan di Indonesia (Mustaqimah et al. 2017).

Namun, tidak semua penelitian menemukan hubungan negatif antara pertumbuhan ekonomi dan kemiskinan. Beberapa temuan juga menyimpulkan bahwa pertumbuhan ekonomi berhubungan positif dengan kemiskinan. (Ahluwalia dan Chenery (1974) menemukan bahwa negara-negara terbelakang yang mengalami pertumbuhan ekonomi secara cepat memberikan sedikit manfaat (sekitar sepertiga dari populasi). Kegagalan pertumbuhan dalam mengurangi kemiskinan disebabkan oleh kegagalan dari trickle down effect. Jadi kemiskinan berlaku meskipun pertumbuhan ekonomi meningkat setiap tahun. Ini berarti bahwa hubungan antara pertumbuhan ekonomi dan kemiskinan bukanlah hubungan kausalitas karena peningkatan pertumbuhan ekonomi tidak sepenuhnya mengurangi kemiskinan. Terciptanya pertumbuhan ekonomi yang inklusif harus memenuhi banyak kondisi dimana semua orang dapat menikmati adanya pertumbuhan ekonomi.

\section{KESIMPULAN}

Adanya temuan yang menunjukkan bahwa hubungan pertumbuhan ekonomi dan kemiskinan yang berbanding lurus (pertumbuhan ekonomi meningkat maka angka kemiskinan meningkat) dan berbanding terbalik (pertumbuhan ekonomi meningkat maka angka kemiskinan menurun). Hasil analisis dan pembahasan menghasilkan kesimpulan bahwa kesempatan kerja mampu memediasi secara parsial antara pertumbuhan ekonomi terhadap kemiskinan di Provinsi DIY selama periode 2000-2017. Dan implikasi dari penelitian ini adalah pentingnya pertumbuhan inklusif yang memberikan akses kepada penduduk miskin terhadap pekerjaan dan kesempatan berusaha. Selain itu, keterbatasan penelitian ini hanya menganalisis hubungan pertumbuhan ekonomi dengan kemiskinan. Dan rekomendasi penelitian selanjutnya bisa memasukan variabel lain seperti investasi atau Indeks Pembangunan Manusia.

\section{DAFTAR PUSTAKA}

Afzal, M., Malik, M. E., Begum, I., Sarwar, K., \& Fatima, H. (2012). Relationship Among Education, Poverty and Economic Growth in Pakistan: An Econometric Analysis. Journal of Elementary Education, 22(1): 23-45

Aghion, P., \& Bolton, P. (1997). A Theory of Trickle-Down Growth and Development. 
The Review of Economic Studies.64 (2): 151-172https://doi.org/10.2307/2971707

Ahluwalia, M.S. Dan H Chenery. (1974). TheEconomic Framework”, In Redistribution with Growth. Oxford Univ. Press. Pp.3-37.

Awandari, L. P. P., \& Indrajaya, I. G. B. (2016). Pengaruh Infrastruktur, Investasi, dan Pertumbuhan Ekonomi Terhadap Kesejahteraan Masyarakat Melalui Kesempatan Kerja. Jurnal Ekonomi PembangunanUNUD, 5(12): 1435-1462. https://doi.org/10.1002/14651858.CD003123.pub3

Badan Pusat Statistik Provinsi Daerah Istimewa Yogyakarta. (2018). Provinsi Daerah Istimewa Yogyakarta Dalam Angka. Badan Pusat Statistik Daerah Istimewa Yogyakarta. Yogyakarta.

Baron, R. M., \& Kenny, D. A. (1986). The Moderator-Mediator Variable Distinction in Social Psychological Research. Conceptual, Strategic, and Statistical Considerations. Journal of Personality and Social Psychology.51(6): 1173-1182. https://doi.org/10.1037/0022-3514.51.6.1173

Berardi, N., \& Marzo, F. (2017). The Elasticity of Poverty with respect to Sectoral Growth in Africa. Review of Income and Wealth. 63(1): 147-168. https://doi.org/10.1111/roiw.12203

Danawati, S., Bendesa, I. K., \& Suyana Utama, M. (2016). Pengaruh Pengeluaran Pemerintah dan Investasi terhadap Kesempatan Kerja, Pertumbuhan Ekonomi serta Ketimpangan Pendapatan Kabupaten/Kota di Provinsi Bali. Bisnis Universitas Udayana. 5(7): 2123-2160. https://doi.org/10.13140/RG.2.1.4708.5283

Datt, G., Ravallion, M., \& Murgai, R. (2016). Growth, Urbanization and Poverty Reduction in India. Nber Working Paper No. 21983. https://doi.org/10.1017/CBO9781107415324.004

Dollar, D., \& Kraay, A. (2002). Growth is Good for the Poor. Journal of Economic Growth 7(3), 195-225.

Ginting, A, M Dan Rasbin. (2010). Pengaruh Pertumbuhan Ekonomi Terhadap Tingkat Kemiskinan di Indonesia Sebelum dan Setelah Krisis, Jurnal Ekonomi \& Kebijakan Publik, 2(1): 276-312

Guiga, H. (2012). Poverty , Growth and Inequality in Developing Countries. International Journal of Economics and Financial Issues, 2(4): 470-479. https://doi.org/10.1016/S0002-9343(03)00057-3

Hasan, R., \& Quibria, M. G. (2002). Poverty and patterns of growth. ERD Working Paper Series No 18.

Hassan, S. A., Zaman, K., \& Gul, S. (2015). The Relationship between Growth-InequalityPoverty Triangle and Environmental Degradation: Unveiling the Reality. Arab Economic and Business Journal. 10(1): 57-71. https://doi.org/10.1016/j.aebj.2014.05.007

Hidayat, Saeful. 2007. Economic Growth, Income Inequality, and Poverty: Estimated Parameter of Poverty Elasticity at Provincial Level in Indonesia at 1996 - 2005. Tesis, Postgraduate University of Indonesia. Depok

Iswara, I. M. A. (2014). Pengaruh Pendapatan Asli Daerah, Pendapatan Per Kapita, dan Tingkat Pendidikan terhadap Tingkat Kemiskinan di Provinsi Bali Tahun 2006 2011. E-Jurnal Ekonomi Pembangunan UNUD. 3(11): 492-501

Jha, R., Biswal, U. D., \& Biswal, B. P. (2000). An Emprical Analysis of the Impact of Public Expenditure on Education and Health on Poverty in Indian States.Queen's Economics Department Working Paper No. 998. https://doi.org/10.2139/ssrn.236888 Jhingan, M.L. 2000. Ekonomi Pembangunan dan Perencanaan. PT Raja Grafindo Persada. 
Jakarta

Jonaidi, A. (2012). Analisis Pertumbuhan Ekonomi dan Kemiskinan di Indonesia. Jurnal Kajian Ekonomi, 1(1): 140-164. https://doi.org/10.1128/AEM.69.5.2624-2630.2003

Kakwani, N., Neri, M. C., \& Son, H. H. (2010). Linkages between pro-poor growth, social programs and labor market: The recent Brazilian experience. World Development. 38(6): 881-894. https://doi.org/10.1016/j.worlddev.2010.02.015

Kuncoro, Murdrajat. (2006). Ekonomi Pembangunan. Penerbit Salemba Empat,Jakarta.

Miranti, R. (2010). Poverty in Indonesia 1984-2002: The impact of growth and changes in inequality. Bulletin of Indonesian Economic Studies. 46(1): 79-97. https://doi.org/10.1080/00074911003642252

Mustaqimah, K., Hartoyo, S., and Fahmi, I. (2017). The Role of Government Capital Expenditures and Human Development Investment on Reducing Poverty in Indonesia. Journal of Development Economics and Policy, 6 (2): 1-15.

Moore, J. D., \& Donaldson, J. A. (2016). Human-Scale Economics: Economic Growth and Poverty Reduction in Northeastern Thailand. World Development, 85: 1-15. https://doi.org/10.1016/j.worlddev.2016.04.004

Paramita, A. A. I. D., \& Purbadharmaja, I. B. P. (2015). Pengaruh Investasi dan Pengangguran Terhadap Pertumbuhan Ekonomi serta Kemiskinan di Provinsi Bali. E-Jurnal Ekonomi Pembangunan.4(10): 1194-1218. https://doi.org/10.1177/001698628703100309

Papilaya, E.C. 2006. Akar Penyebab Kemiskinan Menurut Rumah Tangga Miskin dan strategi Penanggulangannya (kasus di Kota ambon Provinsi Maluku, dan di Kabupaten Boelemo, Provinsi Gorontalo. Disertasi. Bogor: Program Pascasarjana Institut Pertanian Bogor

Siregar, H., \& Wahyuni, D. (2007). Dampak Pertumbuhan Ekonomi Terhadap Penurunan Jumlah Penduduk Miskin. Http://Pse.Litbang.Deptan.Go.Id/Ind/Pdffiles/PROS_2008_MAK3. https://doi.org/http://pse.litbang.deptan.go.id/ind/pdffiles/PROS_2008_MAK3

Soleh, A. (2011). Pertumbuhan Ekonomi dan Kemiskinan di Indonesia.Ekombis, 2(2): 197209. Review. https://doi.org/10.1145/3196398.3196445

Sudaryono (2011) Aplikasi Analisis (Path Analysis) Berdasarkan Urutan Penempatan Variabel dalam Penelitian. Jurnal Pendidikan dan Kebudayaan, 17 (4): 391-403

Sugiyono. (2006). Metode Penelitian Kuantitatif Kualitatif dan R\&D. Bandung: Alfabeta

Sukirno, Sadono. 2010. Makroekonomi: Teori Pengantar. Edisi 3. Jakarta: Rajawali Pers.

Suliyanto. (2011). Ekonometrika Terapan: Teori dan Aplikasi dengan SPSS.. Yogyakarta. ANDI

Suliswanto, M. S. W. (2010). Pengaruh Produk Domestik Broto (PDB) dan Indeks Pembangunana Manusia (IPM) Terhadap Angka Kemiskinan di Indonesia. Jurnal Ekonomi Pembangunan, 8(2): 358-366. https://doi.org/10.22219/JEP.V8I2.3610

Tambunan, T. (2001). Perekonomian Indonesia: Teori dan Temuan Empiris. Jakarta: Ghalia Indonesia

Todaro, Michael P. and Smith, Stephen C. 2011. Economic Development. Eleventh Edition. United States: Addison Wesley

Yarlina, Y. (2012). Pengaruh Tingkat Pengangguran terhadap Tingkat Kemiskinan Kabupaten / Kota di Provinsi Kalimantan Barat. Jurnal Ekonomi Sosial, 8(3): 176185. https://doi.org/10.4324/9780203446515 